\title{
Human Rights in the Criminal Code? A Critique of the Curious Implementation of the EU and Council of Europe Instruments on Combating and Preventing Terrorism in Belgian Criminal Legislation
}

\author{
Steven Dewulf* \\ Faculty of Law, University of Antwerp, Antwerp, Belgium \\ Faculty of Law, Catholic University of Leuven, Leuven, Belgium \\ steven.dewulf@uantwerpen.be
}

\begin{abstract}
Different international instruments on the prevention and suppression of terrorism from the European Union and the Council of Europe task States with adopting new terrorist offences. At the same time, several provisions in these international instruments remind States of their obligation to fully adhere to their human rights obligations when implementing, interpreting and applying these new offences. Following these provisions, Belgium decided to insert a rather curious human rights clause in its Criminal Code. This article will critically examine this peculiar clause and the decision(s) made by the Belgian legislator. The key question is whether or not States should indeed also implement such human rights provisions in their criminal legislation, and if so, in what way they should best proceed. It will be argued that inserting such a specific human rights clause for one particular offence in a domestic criminal code might not only be superfluous, but could even have unforeseen, unwanted and hazardous effects.
\end{abstract}

\section{Keywords}

EU framework decisions - COE convention - terrorism - human rights - specific clause - implementation by states

\footnotetext{
* Lic.Iur./PhD, visiting professor international criminal law at both faculties; lawyer.
} 
As terrorism rose to become one of the most debated crimes of the last decade, the intricate struggle to find a correct balance between efficiently fighting terrorists and respecting human rights turned into a topic of hot debate, spurring a plethora of resolutions, rulings, articles and other statements in which the importance of man's most basic rights was reiterated time and again. ${ }^{1}$ Rule makers themselves also felt the pressure and need to remind the world of the essential prerequisite that human rights could not be violated. ${ }^{2} \mathrm{~A}$ case in point is the well-known Framework Decision 2002/475/JHA of 13 June 2012 on combating terrorism that was drafted by the Council of the European Union. ${ }^{3}$ The essential purpose of this instrument was to ensure that terrorist offences would be criminalised in a similar manner in all EU Member States. The Council was nonetheless aware of the possible conflict between this Framework Decision and certain basic rights. The definition of a terrorist offence in Article 1(1), for instance, was vague and quite broad, as was the rather generic interpretation of a terrorist group, ${ }^{4}$ which could possibly lead to the criminalisation of legitimate conduct. Therefore, it clearly stipulated in Article 1(2) that the Framework Decision would not in any way change the obligation to respect fundamental rights and fundamental legal principles as enshrined in Article 6 EU Treaty. The Council had already explained in preambular paragraph 10 that the Decision could not be interpreted as being intended to reduce or restrict fundamental rights or freedoms such as the right to strike and freedoms of assembly, association or expression, including the rights of everyone to form and join trade unions and to demonstrate.

1 See, among a great many other sources, UNGA Res. 66/282, 29 June 2012, The United Nations Global Counter-Terrorism Strategy Review, UN Doc. A/RES/66/282, preambular para. 6 and para. 9; ECtHR, A. and Others $v$. United Kingdom, Appl. No. 3455/05, Judgment 19 February 2009, para. 126, available online at http://www.echr.coe.int; Y. Ginbar, Why not Torture Terrorists? (Oxford: Oxford University Press, 2008); N. Norberg, 'Terrorism and International Criminal Justice', 8 Santa Clara Journal of International Law (2010) pp. 27-49; S. Sottiaux, Terrorism and the Limitation of Rights (Oxford: Hart Publishing, 2008).

2 See, e.g., the Security Council itself, which in Resolution 1624 (2005) called upon States to adopt measures to prohibit incitement to commit terrorist acts and to prevent such conduct, but also stressed that States had to ensure that measures taken to implement the resolution comply with all of their obligations under international law, in particular international human rights law, refugee law, and humanitarian law. See SC Res. 1624, 14 September 2005, UN Doc. S/RES/1624 (2005), paras 1 and 4.

3 OJ L 164, 22.6.2002, p. 1 (hereafter 'EU Council Framework 2002/475/JHA').

4 And the offences related to a terrorist group, see Article 2 Framework Decision 2002/475/JHA. 
When the Council amended its Framework Decision in 2008, the matter became even more acute. Framework Decision 2008/919/JHA of 28 November 2008 amending Framework Decision 2002/475/JHA on combating terrorism ${ }^{5}$ was the result of the evolution of the terrorist threat and the changes in the modus operandi of the terrorist activists and their supporters. ${ }^{6}$ As stipulated in preambular paragraph 7 , this new Framework Decision wanted to contribute to a more general policy of preventing terrorism through reducing the dissemination of those materials which might incite persons to commit terrorist attacks. It did so by providing in the criminalisation of actions that were linked to terrorist activities, in particular the public provocation to commit a terrorist offence, the recruitment for terrorism and the training for terrorism. ${ }^{7}$ This expanded the scope of criminal conduct in a fairly substantial manner. The problem was not that, for instance, actual terrorist recruiters could be held criminally responsible, which almost everyone could agree on. It was rather that it was unclear when a person actually became a terrorist recruiter, provocateur or trainer. Or, otherwise said, when a person started to become a criminal. Holding and expressing a different opinion, criticizing the authorities, protesting or being a member of an unconventional group suddenly became far more hazardous. Aware of the fact that this (perhaps necessary but still radical) new initiative put core rights even more at stake, the Council did not just insert a generic provision similar to Article 1(2) Framework Decision $2002 / 475 / \mathrm{JHA}$ in the amending instrument. The Council emphasised the fundamental importance of human rights in the preamble of this new instrument in a more detailed manner, and also specifically mentioned the right to respect for private and family life, including the right to respect confidential correspondence. ${ }^{8}$ But it went even further and inserted an entire Article 2 in Framework Decision 2008/919/JHA dedicated to 'fundamental principles relating to freedom of expression', in which it stipulated that this instrument would not have the effect of requiring Member States to take measures in contradiction of fundamental principles relating to the freedom of expression, in particular the freedoms of the press and expression in other media. As if this was not already considered enough, the Council also added in Article 3(1) that Member States, when implementing this Framework Decision, had to ensure that the criminalisation would be proportionate to the legitimate aims

5 OJ L 330, 9.12.2008, p. 21 (hereafter 'Framework Decision 2008/919/JHA').

6 See preambular paragraph 3 Framework Decision 2008/919/JHA.

7 See Article 1 Framework Decision 2008/919/JHA.

8 See preambular paragraph 13 Framework Decision 2008/919/JHA. 
pursued and necessary in a democratic society, and would exclude any form of arbitrariness and discrimination.

It should be recognised, though, that the Council of the European Union was not the only one to have proceeded in this manner. On 16 May 2005, the Council of Europe had already adopted a convention ${ }^{9}$ with a very similar aim and object, namely to criminalise the public provocation of and recruitment and training for terrorism..$^{10}$ It too contains a specific Article 12 on the conditions and safeguards which States must respect. According to this provision, all States Parties are obliged to establish, implement and apply the criminalisation under the COE Convention while respecting human rights obligations, in particular the right to freedom of expression, freedom of association and freedom of religion, as set forth in the ECHR, ICCPR and other obligations under international law.11

As a result of this all, the human rights debate was not just made a part of the counter-terrorism effort, but it was even put at the heart of it. The purpose of this particular article, however, is not to discuss in detail the relationship between observing human rights and combating terrorism. It is not going to focus on the issue of defining terrorism and terrorist offences ${ }^{12}$ - at least not

9 Council of Europe Convention on the Prevention of Terrorism, Warsaw, 16.V.2005, CETS No. 196 (hereafter 'COE Convention on the Prevention of Terrorism').

10 See Articles 5, 6 and 7 COE Convention on the Prevention of Terrorism.

11 Furthermore, Article 12(2) COE Convention on the Prevention of Terrorism is similar to Article 3(1) Framework Decision 2008/919/JHA and also refers to the principle of proportionality and the obligation to exclude any form of arbitrariness or discriminatory or racist treatment. In the preamble, it is also reaffirmed that all measures taken to prevent or suppress terrorist offences have to respect the rule of law and democratic values, human rights and fundamental freedoms as well as other provisions of international law. Moreover, it is also noted that the Convention is not intended to affect principles relating to the freedoms of expression and association.

12 See on this topic i.a. E. Dumitriu, 'The E.U.'s Definition of Terrorism: The Council Framework Decision on Combating Terrorism', 5 German Law Journal (2004) pp. 575-602; B. Golder and G. Williams, 'What is ‘Terrorism'? Problems of Legal Definition', 27 University of New South Wales Law Journal (2004) pp. 270-295; L. Mellinger, 'Illusion of Security: Why the Amended EU Framework Decision Criminalizing 'Incitement to Terrorism' on the Internet Fails to Defend Europe from Terrorism', 37 Syracuse Journal of International Law and Commerce (2009-2010) pp. 354-355; C. Begorre-Bret, 'The Definition of Terrorism and the Challenge of Relativism', 27 Cardozo Law Review (2005-2006) pp. 1987-2004; J.J. Paust, 'Terrorism's Proscription and Core Elements of an Objective Definition', 8 Santa Clara Journal of International Law (2010) pp. 51-67; M.J. Borgers, 'Framework Decision on combating terrorism: two questions on the definition of terrorist offences', 4 New Journal of European Criminal Law (2012) pp. 68-82. 
directly -, examine the merits and flaws of the new European instruments ${ }^{13}$ or completely analyse the Belgian implementation of these three international instruments. ${ }^{14}$ This article will focus on one specific issue, namely on the question whether or not a State should also implement such human rights provisions in its criminal legislation, and if so, in what way it should best proceed. In doing so, this article will be structured as follows: in a second part, it will first be explained how Belgium transposed the European human rights provisions in its domestic legislation. In a most important third part, the approach taken by Belgium will be critically assessed and it will be argued that this initiative, even if laudatory in principle, is not advisable and may even prove to be dangerous. In a final part, concluding observations will be made.

\section{Implementing the European Instruments in the Belgian Criminal} Code

\subsection{New Article 14ter of the Belgian Criminal Code}

Framework decisions adopted on the basis of former Article 34 EU Treaty needed to be implemented by the Member States. EU States were given until 31 December 2002 to take all necessary measures to comply with Framework Decision 2002/475/JHA, but the Belgian legislator only transposed this instrument with the Law of 19 December 2003. ${ }^{15}$ This Law inserted a new Title Iter in the Belgian Criminal Code, ${ }^{16}$ which was essentially meant to criminalise

13 See i.a. S. Glass, 'The Two Framework Decisions. A critical approach' in F. Galli and A. Weyembergh (eds), EU counter-terrorism offences. What impact on national legislation and case-law? (Brussels: Editions ULB, 2012) pp. 33-46; E. Dumitriu, op. cit., pp. 589-602; L. Mellinger, op.cit., pp. 339-368.

14 See i.a. V. Hameeuw, 'Strafbaarstelling van terroristische misdrijven: van Europees Kaderbesluit tot het Belgisch Strafwetboek [Criminalisation of terrorist offences: from European Framework Decision to the Belgian Criminal Code]', 6 Tijdschrift voor Strafrecht (2005) pp. 2-12; M.-A. Beernaert, 'La loi du 19 décembre 2003 relative aux infractions terroristes: quand le droit pénal belge évolue sous la dictée de l'Union européenne [The law of 19 December 2003 regarding terrorist offences: when Belgian criminal evolves under pressure of the European Union]', 123 Journal des Tribunaux (2004) pp. 585-590; A. Weyembergh and L. Kennes, 'Domestic provisions and case law: The Belgian Case' in F. Galli and A. Weyembergh (eds), EU counter-terrorism offences. What impact on national legislation and case-law? (Brussels: Editions ULB, 2012) pp. 149-166.

15 Official Gazette 29 December 2003.

16 Hereafter 'C.C.' 
terrorist offences, ${ }^{17}$ offences pertaining to terrorist groups ${ }^{18}$ and a specific offence pertaining to the provision of material assistance with the aim of committing a terrorist offence. ${ }^{19}$ In addition, and the focal point of this analysis, Article 9 of this Law also provided for the inclusion of a rather curious Article 141 ter C.C, which stated that no provision of Title Iter could be interpreted in such a manner as being intended to reduce or restrict rights or fundamental freedoms, such as the right to strike, the freedoms of assembly, of association or of expression, including the right to form or join trade unions with others for the protection of proper interests, and the related right to demonstrate, as set forth in inter alia Articles 8 to 11 ECHR.

When the European legislator adopted Framework Decision 2008/919/JHA, States were asked to take all necessary implementation measures by 9 December 2010. However, it was not until very recently, on 18 February 2013, that Belgium adopted a new Law 'to modify Book II, Title Iter of the Criminal Code. ${ }^{20}$ While the prime aim was obviously to also criminalise the new forms of behaviour which the European legislators ${ }^{21}$ had identified, ${ }^{22}$ the Belgian authorities also deemed it appropriate to amend Article 141ter Belgian C.C. In particular, Article 8 of the new Law of 2013 put forward that the wording of Article 141ter C.C. was to be replaced with the following even more specific text:

No provision of this title can be interpreted in such a manner as being intended to reduce or restrict rights or fundamental freedoms in an unjustified manner, such as the right to strike, the freedom of assembly and association, including the right to form or join trade unions with others for the protection of proper interests, and the related right to demonstrate, the freedom of expression, in particular the freedom of the press and the freedom of expression in other media, as set forth in inter alia Articles 8 to 11 ECHR. ${ }^{23}$

17 Articles 137-138 Belgian C.C., implementing Article 1 and 5 Framework Decision 2002/475/ JHA.

18 Articles 139-140 Belgian C.C., implementing Article 2 and 5 Framework Decision 2002/475/ JHA.

19 Article 141 Belgian C.C. This provision is an implementation of an obligation stemming from the International Convention for the Suppression of the Financing of Terrorism, New York, 9 December 1999, 2178 UNTS, 197.

$20 \quad$ Official Gazette 4 March 2013.

21 The Law implemented Framework Decision 2008/919/JHA and COE Convention on the Prevention of Terrorism.

22 See especially Article 140bis, 140ter, 140quater and 140quinquies Belgian C.C., as inserted by Articles 4-7 Law of 2013.

23 Personal translation. Dutch version of new Article 141ter C.C.: 'Geen enkele bepaling uit deze titel kan worden gelezen in die zin dat zij een niet verantwoorde beperking of 
As a consequence, there is now a provision in the middle of the Belgian Criminal Code, which does not criminalise specific conduct or stipulate which punishment should be imposed, but rather reminds all those involved that no provision on terrorist offences may ever be interpreted or applied in a manner that would be contrary to human rights and fundamental freedoms.

\subsection{A Superfluous Provision}

All should agree that Article 141ter C.C. is absolutely correct, as regards content at least: the State, in particular its prosecuting authorities and courts, must abide by human rights when interpreting and applying specific terrorism provisions. It is also understandable that international (political) organs and drafters of treaties found it helpful — and even necessary — in light of all that has happened to remind Member States explicitly of the prohibition to consider or use their new instruments in violation of basic rights and freedoms. The more radical, intrusive and questionable a measure becomes, the more the pressure could be felt to compensate by emphasising existing human rights obligations. It might be that inserting such a clause was considered a means to highlight that, according to the international drafters, the new obligations were created while considering human rights. ${ }^{24}$ However, it is important not to overlook the fact that all relevant European instruments as such still needed (or need) to be implemented by Member States either. Both the Framework Decisions and the COE Convention stipulate that States are to adopt all necessary measures in order to make sure that the new offences are included in their respective criminal legislation. ${ }^{25}$ This is not just a matter

belemmering beoogt van rechten of fundamentele vrijheden, zoals het stakingsrecht, de vrijheid van vergadering en vereniging, waaronder het recht om, voor de verdediging van de eigen belangen, samen met anderen vakbonden op te richten dan wel zich erbij aan te sluiten, evenals het daarmee samenhangende recht van betoging, de vrijheid van meningsuiting, in het bijzonder de vrijheid van drukpers en de vrijheid van meningsuiting in andere media, en zoals onder meer verankerd in de artikelen 8 tot 11 van het Europees Verdrag tot bescherming van de rechten van de mens en de fundamentele vrijheden.'

24 See, e.g., the comments of the Commission in the explanatory memorandum to the Proposal for a Council Framework Decision amending Framework Decision 2008/919/ JHA on combating terrorism, Brussels, 6 November 2007, $\operatorname{COM}(2007) 650$ final, p. 4, which might hint at the creation of some sort of presumption of legitimacy for the new offences (see also infra Section III. (4)).

25 See Articles 1-5 and 11 Framework Decision 2002/475/JHA, Article 3 Framework Decision 2008/919/JHA and Articles $5^{-7}$ COE Convention on the Prevention of Terrorism. 
of copy-pasting. States are often left with a certain margin of appreciation as regards the final implementation of such instruments. In delicate matters or when an element is topic of debate, it is not uncommon for international drafters to even remain vague or ambiguous about certain aspects on purpose.

Whatever the case may be, the international drafters felt the need in this case to remind States of the direct obligation to make sure that the criminal provisions they would adopt, would be in line with human rights principles. The importance of this aspect should not be underestimated. As is for instance observed in the Explanatory Report of the COE Convention, the inclusion of several provisions concerning the protection of human rights in this treaty was a crucial aspect, given that the Convention deals with issues which are on the border between the legitimate exercise of freedoms and criminal behaviour. ${ }^{26}$ States and their authorities might indeed be confronted with difficult situations which could potentially fall under the criminal provisions drafted on the basis of those European instruments, but only if certain human rights would be restricted, bent or put aside. It could then be argued that those other European law instruments, which actually imposed the specific duty to criminalise these offences, simultaneously authorised to supersede the applicable human rights principles. In order to avoid any confusion in this respect, and possibly also under external pressure ${ }^{27}$ or to thwart or rebuff criticism that the international drafters themselves wanted to override human rights protection, such specific human right provisions were included in the different instruments. ${ }^{28}$ But does this mean that such clauses must also be implemented by States in their domestic legislation? Even though nothing in the language of the relevant provisions of the European instruments directly suggests such a

26 Explanatory Report, Council of Europe Convention on the Prevention of Terrorism (CETS No. 196), paras 29-30, available online at http://www.conventions.coe.int/Treaty/EN/ Reports/Html.196.htm.

27 The ICJ, e.g., strongly advocated for the inclusion of such a human rights provision in Framework Decision 2008/919/JHA, in order to emphasise that the new instrument did not require or encourage the creation of excessively broad offences. International Commission of Jurists, Briefing paper: Amendment to the Framework Decision on Combating Terrorism - Provocation to Commit a Terrorist Offence, available online at http://www.un.org/en/sc/ctc/specialmeetings/2011/docs/icj/icj-2008-fd2007-650.pdf.

28 From a completely opposite point of view, Glass suggests that Article 2 could potentially also be used by States, for instance, before the ECJ in case the EU would claim that they did not fully implement European terrorism legislation and had made overly lenient penal statutes, Sabine Glass, op.cit., p. 44. 
view, ${ }^{29}$ the Belgian legislator, in contrast to legislators in other European countries, ${ }^{30}$ apparently felt it did.

The idea to also insert an Article 141ter in the Criminal Code fell somewhat from the sky while drafting the Law of 2003. The Belgian government had not included it in its original draft bill, and the insertion of this provision was only proposed in an amendment. ${ }^{31}$ The minister of Justice later explained that this clause was intentionally inserted in order to maintain the balance between fighting terrorism and respecting fundamental values. In these matters, the minister noted, it was better to be needlessly explicit than dangerously silent and ambiguous. ${ }^{32}$ Some members of parliament, however, questioned this insertion, and rather correctly asked whether the obligation to respect human rights was not self-evident. ${ }^{33}$ In effect, this seems to be the crucial question surrounding this human rights clause: is it simply not redundant? That was also the general feeling with which this clause was greeted in the scholarly world. ${ }^{34}$ Should human rights and fundamental freedoms not be respected per se by States and their authorities when drafting, inserting, interpreting and applying criminal provisions? ${ }^{35}$ Even though there might be good or understandable reasons behind the inclusion of such provisions in the European instruments by their respective drafters, that does not mean that States must also insert such clauses in their criminal legislation. Yet, even though the Belgian legislator itself did acknowledge that such a provision was essentially superfluous, it still decided on keeping it because it was considered a valuable "reminder" of the principles regarding the application of fundamental

29 The Council of State argued that Framework Decision 2008/919/JHA did not impose a duty to implement Article 2 in the form of Article 141ter C.C., Advice Council of State, Parl. Doc. Chamber of Representatives 2012-13, 2502/o01, p. 27. See also S. Glass, op. cit., at p. 44, who states that the legal effect of Article 2 remains unclear.

30 See, e.g., the Netherlands (Law of 24 June 2004, Staatsblad 2004, 240 and Law of 12 June 2009, Staatsblad 2009, 245), France (Article 421-1 to 422-7 French Criminal Code); and Spain (Article 571-580 Spanish Criminal Code), which did not include a similar provision in their terrorism legislation.

31 See in particular Parl. Doc. Chamber of Representatives 2003-04, 0258/003, p. 5 .

32 Parl. Doc. Chamber of Representatives 2003-04, 0258/004, p. 11.

33 Ibid., p. 23.

34 See, e.g., A. Masset, 'Terrorisme [Terrorism]' in X, Postal Memorialis, June 2012, T-9o/14; M.-A. Beernaert, op.cit., p. 588; P. Traest, 'Ontwikkeling van nieuwe deelnemingsvormen [Development of new forms of participation', 2 Nullum Crimen (2007) pp. 241-262; V. Hameeuw, op. cit, p. 10; A. Weyembergh and L. Kennes, op.cit., p. 155.

35 That does not mean that human rights are always respected, but actions that violate human rights are illegal. 
freedoms in a democracy. ${ }^{36}$ Thus the curious Article 141ter came to be in the Criminal Code.

When in late 2012 the Belgian government submitted a draft bill to amend Title Iter C.C. in order to incorporate the provisions from Framework Decision 2008/919/JHA and the COE Convention on the Prevention of Terrorism, it also decided to revisit Article 141ter C.C. Although it was once again recognised that such a provision was not necessary, ${ }^{37}$ the legislator still decided to keep it, basically because it felt that the importance of respecting human rights could not be overemphasised. The fact that the Council of the European Union had decided to integrate the preambular paragraph on human rights in its first Framework Decision into an actual and binding Article 2 in its second Framework Decision, was considered a strong argument to further stick to the chosen path, ${ }^{38}$ notwithstanding the original criticism on Article 141ter C.C. and, in particular, the clear statement by the Belgian Council of State that such a provision should simply be left out. ${ }^{39}$ The legislator felt that such a provision would give judges an important guideline, ${ }^{40}$ which could assist them in their task of evaluating and deciding whether certain conduct ought to be regarded as a forbidden terrorist offence. ${ }^{41}$

As a result, one might conclude that Article 141ter C.C. is essentially redundant and does not add anything new, but could still have its merits, even if just as an interpretation tool, given the delicate and grave nature of the topic at hand and the legal clauses on the matter in the European instruments of origin. This is, however, not the conclusion that will be drawn here, quite the opposite even. A member of Belgian parliament questioned whether such a clause would not tamper with investigations into terrorist activities, ${ }^{42}$ but this is not the type of preoccupation that underlies this argument: it is the importance of the full respect for human rights which motivates the remainder of this analysis.

36 Parl. Doc. Chamber of Representatives 2003-04, 0258/004, p. 24.

37 See, e.g., also Parl. Doc. Senate 2012-13, 5-1905/3, p. 19.

38 Parl. Doc. Chamber of Representatives 2012-13, 2502/o01, pp. 16-18.

39 The Council of State (legislative branch) was mandated with assessing both draft bills (2003 and 2012) as regards content, style, legislative quality... However, given that the original suggestion to insert Article 141ter was only made after the Council of State had given its advice on the proposal for the original draft bill of 2003, it never had the chance to give its opinion on the matter. In 2012, nonetheless, it was quite clear. See Advice Council of State, Parl. Doc. Chamber of Representatives 2012-13, 2502/oo1, pp. 27-28.

40 Parl. Doc. Chamber of Representatives 2012-13, 2502/004, pp. 5-6.

41 Parl. Doc. Chamber of Representatives 2012-13, 2502/001, p. 18.

42 Parl. Doc. Chamber of Representatives 2003-04, 0258/004, p. 24. 
It is in effect not just a case of having a superfluous insertion of a well-known and already established principle. There are a number of reasons for which such an explicit confirmation of the need to respect human rights within a criminal provision is not just needless, but should also be considered unwise and could even have some unforeseen and dangerous effects. ${ }^{43}$

\subsection{A Criminal Code Should First and Foremost Contain Crimes, Not Human Rights}

The essence of a criminal code is that it contains rules and principles relating to criminal law. Now it is true that human rights and criminal law are much intertwined. The principle of legality, for instance, is the most basic principle of criminal law and a recognised a human right. ${ }^{44}$ The violation of different human rights is, moreover, often considered a crime: torture, ${ }^{45}$ murder, ${ }^{46}$ some forms of discrimination ${ }^{47}$ etc. It is also within a criminal context that human rights are (most, one might say perhaps) at risk of being violated. One could hence very well argue that the need to respect fundamental rights and freedoms could, and perhaps should, be recognised explicitly in a criminal code. The principle of legality is, for example, already proclaimed at the very beginning of the Belgian Criminal Code, ${ }^{48}$ and a more general provision could also be envisioned. It could be stated that every rule and provision of the criminal code should be interpreted and applied in a manner that is consistent with human rights. In fact, such a provision has already been included in Article 21(3) Statute ICC, ${ }^{49}$ which could therefore be regarded as an example.

43 Note that the flaws and potential hazards of Article 14iter C.C. will be discussed in a comprehensive and systematic manner. One might be inclined to feel as if some of these issues only pertain to Article 141ter C.C. (e.g., inaccurate wording), and are as such not representative but mere details. But the purpose is to identify in an abstract manner, on the basis of Article 141ter, all elements that need to be taken into account when drafting such a clause.

44 It is, e.g., included in Article 15 ICCPR, Article 7 ECHR and Article 49 EU Charter of Fundamental Rights.

45 E.g., criminalised in Article 417 bis and 417 ter C.C. (cf., Article 3 ECHR).

46 E.g., criminalised in Article 394 C.C. (cf., Article 2 ECHR).

47 Discriminatory intent is frequently identified as an aggravating circumstance in the Belgian Criminal Code, see, e.g., Article 438bis, 442ter and 453bis C.C.

48 See Article 2 C.C.

49 Article 21(3) Statute International Criminal Court (hereafter 'Statute ICC'): 'Applicable law... The application and interpretation of law pursuant to this article must be consistent 
There is, nonetheless, a fundamental difference between inserting such a general provision in a statute of an international court on the one hand and in a specific provision of a domestic criminal code, relating to just one crime, on the other. Firstly, given the fact that when the Rome Statute was drafted, there was still uncertainty about the rules, principles and laws the International Criminal Court (and other Tribunals for that matter) were to apply, it could not harm to reiterate explicitly that this international jurisdiction - which is not a party to any international human rights instruments - and all of its organs were also bound by human rights. Stating the obvious at a moment that it was not necessarily so obvious, just to make it obvious. Matters are different for States, though, seeing as they must necessarily and evidently respect the most basic rights of persons. This most essential obligation is not only included in constitutions of States but many if not all States have long been party to different human rights treaties and conventions. The European Court of Justice, for instance, just emphasised that the EU Charter of fundamental rights is directly binding for Member States when implementing EU legislation, as is the case in casu concreto. ${ }^{50}$ As a result, there is a clear, longstanding and unequivocal obligation for all States to respect human rights in everything they do. In this regard, it seems redundant to repeat the obvious which is and has always been obvious in a criminal code, even if one could appreciate the specific importance of respecting human rights in the field of criminal law and, therefore, accept such a provision due to their special relationship. Still, in the end, human rights first and foremost belong in a specific treaty or in a constitution, whereas a criminal code should first and foremost focus on criminal rules and crimes.

Secondly, even if one could accept such a provision in a criminal code, it then still is very important to know where exactly to insert it. The Belgian Criminal Code consists of two books: a first book that contains general rules and principles ${ }^{51}$ and a second book with a very long list of particular offences. ${ }^{52}$ If one would be determined about inserting such a human rights provision,

with internationally recognized human rights, and be without any adverse distinction founded on grounds such as gender as defined in article 7, paragraph 3, age, race, colour, language, religion or belief, political or other opinion, national, ethnic or social origin, wealth, birth or other status'.

50 ECJ, Åklagaren v. Hans Åkerberg Fransson, Case C-617/10, Judgment, 26 February 2013, curia.europa.eu.

$5^{1}$ Rules on the types of punishments, repetition of offences, mitigating circumstances etc., Article 1-10oter C.C.

$5^{2}$ Articles 101-566 C.C. 
surely it would have to be in the first book, preferably somewhere in the beginning. The comparable human rights provision that can be found in the Statute of the International Criminal Court is similarly included in a separate article entitled "Applicable Law", which relates to the entire legal framework that the Court needs to apply and respect. By contrast, it is not inserted in the provisions that deal specifically with the crimes of aggression, genocide, crimes against humanity or war crimes..$^{53}$ On this point, the Belgian legislator seems to have made a first unadvisable call, since its - perhaps defendable or at least understandable - urge or preoccupation to emphasise the need to respect the human rights framework was expressed in Article 141ter of Book II of the Criminal Code. In a long list of provisions that deal almost exclusively with defining and punishing crimes, one provision of the sudden reminds us of the need to respect human rights. This seems a bit peculiar, even though it is not the only provision in Book II that does not deal directly with the criminalisation or punishment of specific conduct. There are also provisions with definitions of terminology that is used, ${ }^{54}$ articles that exclude the application of certain grounds of justification for particular crimes ${ }^{55}$ and also articles that contain very specific guidelines for the interpretation of offences. ${ }^{56}$ A provision that does not criminalise or punish particular behaviour is, as a result, not completely unheard of. More concerning, however, is the fact that it only relates to that one specific category of terrorist offences.

\subsection{The Respect for Human Rights May Appear to Be Less Important in Case of Other Offences}

Fighting terrorists while respecting human rights can be very difficult, but is nonetheless essential. This is the basic message the Belgian legislator wanted to convey in its Criminal Code. It is aware of this difficult struggle and it wanted to make clear that it is neither its wish nor its intention to restrict fundamental rights and freedoms in any way, let alone to take the fight against terrorism out into the field of lawlessness. Again, one can relate.

However, this statement by the legislator risks being misunderstood. Not even taking into account that the (previous) criminalisation of other offences

53 See Articles 6-8bis Statute ICC.

54 See, e.g., Article 135 C.C. (regarding the definition of 'weapons' that can be used in crimes against state security).

55 See, e.g., Article 417ter C.C. (in case of torture, a state of necessity cannot justify the crime).

56 See, e.g., Article 324 bis, para. 2 C.C. (regarding the definition of a criminal organisation), which actually contains wording that is identical to Article 139 of the Criminal Code (regarding the definition of a terrorist group). 
could have a similar (questionable) impact on certain fundamental rights and freedoms, one should be wary about interpreting the message of the legislator in the wrong way, as if it wanted to say "we care about fundamental rights in case of terrorism, but in other instances, not so much". It seems to speak for itself that this is what the legislator meant to say. Yet by only including such a clause for one specific category of offences, the question is still begged: why not for other crimes? Are they less important? Or even worse, are human rights less important in their case? Arguably, terrorist offences seem to raise more human rights related questions than other crimes. It is true that it seems more straightforward to prosecute a person for rape than for uttering an opinion or giving a lesson. But this does not imply that human rights are less important in case of other offences than in case of terrorism. Authorities, judges in particular, might also be confronted with other instances of questionable behaviour that might seem to balance between forbidden criminal activities and protected fundamental freedoms. In those instances, the authorities should not close their eyes to the human rights principles, but respect them in exactly the same manner. They are legally bound do so, even if Article 141 ter C.C. may give way to a different reading — which brings about a third critique.

\subsection{Even Without Explicit Confirmation Human Rights Are to Be Respected}

The Belgian Council of State noted that Article 141ter Belgian C.C. is not only superfluous but also confusing in that it may give the impression that without the insertion of an article to the contrary, the criminal provisions relating to terrorist offences could lawfully be interpreted in a manner contrary to human rights. ${ }^{57}$ In other words, it could be implied from this approach that without such a provision, human rights could legally be violated by a judge or another authority when interpreting the core criminal provisions on terrorism; hence the need to include such a provision. The Council of State therefore recommended deleting this provision in order to prevent such reasoning. Seeing as the Belgian legislator refused to follow this advice, one could argue that this interpretation has not been rebuffed. In addition to raising important questions about the specific rights and treaties that are mentioned in Article 141ter C.C., 58 this could also lead to the conclusion that such a provision should always be included, id est, for every offence, if human rights are to be

57 Advice Council of State, Parl. Doc. Chamber of Representatives 2012-13, 2502/001, p. 28.

$5^{8} \quad$ Infra Section III (6). 
respected. ${ }^{59}$ Because the Belgian legislator evidently did not foresee such a human rights clause for all the offences in its Criminal Code, the conclusion could be drawn that courts and other authorities may in these cases legally interpret all relevant criminal provisions while violating human rights. Thus the legal protection of the most basic rights would be made moot and ineffective in all cases except for terrorism.

Of course, such an interpretation would again be fundamentally flawed. Even if the legislator would have thought about this interpretation and actually chose to follow it — quod non - then it would still simply be wrong and illegal. Human rights and fundamental freedoms need to be respected as a rule, ${ }^{60}$ whether or not this is explicitly said in the law in question, just because it is one of the State's most basic international, European and constitutional obligations. Particular reference must be made in this respect to the ECHR and EU Charter, which naturally apply in non-terrorism cases as well. ${ }^{61}$ The fact that this has not been stipulated as regards other criminal offences does not change anything about the need and plight to respect human rights in the same manner. Yet by wanting to be too clear for terrorist offences, ${ }^{62}$ the legislator opened the door for such an incorrect reading for all other types of criminal misconduct. What's worse: if it were to repeat this initiative in the future, such an incorrect reading would be given renewed support. If the legislator did it once, it could have been hasty, overzealous or plain wrong. If it did it again, it might want to send an actual message, or at least that is how it might be understood - an interpretation that could actually undermine the status and nature of i.a. the European human rights Convention and Charter.

\subsection{This Type of Clause Might Create a Presumption That the Terrorist Offences As Such Are in Conformity with Human Rights Principles}

By stating that no provision of Title Iter of the Belgian Criminal Code may be interpreted in a manner that is inconsistent with human rights principles, the

59 As one member of parliament also observed, see Parl. Doc. Chamber of Representatives 2003-04, 0258/004, p. 24. See also V. Hameeuw, op.cit., p. 10.

6o Be it that several human rights treaties do permit States to derogate, under certain conditions, from certain obligations in exceptional circumstances, such as war or another public emergency threatening the life of the nation. See. e.g.. Article 4 ICCPR and Article 15 ECHR.

61 Be it that there are also important limits to the field of application of the EU Charter (see in particular Article $5_{1}$ EU Charter).

62 It was observed by one member of Parliament that the special nature of terrorist offences warranted the inclusion of such an explicit human rights clause. However, this member also stated that such an approach might also be justified when creating other offences. 
presumption seems to be that the offences as such are essentially in accordance with the core rights framework. This, however, is open to discussion. The Ligue des Droits de l'Homme, for instance, has long been very critical about the Law of 2003, which implemented Framework Decision 2002/475/JHA. It instituted proceedings before the Belgian Constitutional Court in order to have the Law annulled, amongst other things because it claimed that the new offences were in violation of the principle of legality and the prohibition of discrimination. Even though in the end, the Court ${ }^{63}$ did not agree with the applicant, it was a margin call. ${ }^{64}$ The new offences that were inserted by the Law of 2013, conversely, have not (yet) been examined or approved by the Constitutional Court. The Council of State did raise some human rights concerns, ${ }^{65}$ although it considered that the provisions of the draft bill were in accordance with the principle of legality. The Ligue nevertheless indicated that it had fundamental reservations about these new provisions from a human rights perspective. Thus, when in 2012 it was invited by the Belgian Senate to give its opinion on the draft bill, it stated that the legality principle and the freedoms of expression, press and association were put at risk. Even though different members of the Assembly agreed with the Ligue, the bill was accepted as it was, without any additional changes being made. 66

But even leaving aside the specific question of whether or not the current provisions are in accordance with basic human rights principles, just imagine that Title Iter would be amended again. What if the legislator would decide that crimes must be added, which are even more suspicious from a human rights perspective? By then simply referring to this human rights clause, it could be inferred that there is a legal assumption that all offences to which the clause applies are in accordance with human rights, hence making it

Parl. Doc. Chamber of Representatives 2003-04, 0258/004, p. 24. It was left open, nonetheless, if and when other justified situations could present themselves.

63 The Council of State had already concluded in its advice regarding the Law of 2003 that, in principle, the draft criminal provisions did not violate the principle of legality, see Advice Council of State, Parl. Doc. Chamber of Representatives 2003-04, 0258/o01, pp. 24-31.

64 See Arbitration Court 13 July 2005, No. 125/2005, Official Gazette 3 August 2005, pp. B.6.2-B.7.4 (principle of legality) and B.9-B.11.4 (discrimination) (the Court still carried the name Arbitration Court at the time).

65 In particular with regard to the freedom of expression. See Advice Council of State, Parl. Doc. Chamber of Representatives 2012-13, 2502/o01, pp.23-27.

66 Parl. Doc. Senate 2012-13, 5-1905/3/oo1, pp. 6, 12 and 16-24. See also previously Parl. Doc. Chamber of Representatives 2012-13, 2502/004, pp. 5-6. The Ligue and others, nonetheless, subsequently instituted proceedings before the Constitutional Court on 5 September 2013 to have certain provisions of the Law of 2013 annulled, because they would be in violation of different fundamental rights. The Court has yet to rule in this case. 
more difficult to proof the contrary. In doing so, the authorities could have given themselves the benefit of the doubt, even in very questionable situations.

\subsection{The Legislator Used Ambiguous and Imprecise Wording}

Article 141ter C.C. furthermore illustrates the importance and difficulty of choosing correct wording for a human rights clause, as it shows, or showed, several flaws. To start with, Article 141ter C.C. states that 'rights and fundamental freedoms' ${ }^{\prime 67}$ cannot be reduced or restricted. Even though it may be assumed that the Belgian legislator only wished to refer to human rights, one cannot but notice that it did not do so. It could have easily avoided any confusion by simply having added the word 'human' before 'rights', but by not doing so it left unnecessary room, even if only limited, for misinterpretations. ${ }^{68}$

In addition, the Council of State correctly underscored that if the legislator truly wanted to insert such a human rights clause, it should make sure that this rule would be encapsulated in correct terms. It observed that in the original draft bill submitted by the government it was stated that no provision of Title Iter could be interpreted in such a manner as being intended to reduce or restrict rights or freedoms, ${ }^{69}$ whereas the new offences evidently and essentially reduce certain fundamental rights, such as the freedoms of expression and association. The Council of State therefore advised to change this into prohibited unjustified reductions and restrictions, ${ }^{70}$ which the legislator accepted to do. ${ }^{71}$ The draft bill was in effect legally unsound. It was not in accordance with established principles of human rights law, which do allow for justified restrictions of (certain) human rights, such as the freedoms of expression ${ }^{72}$ or of assembly ${ }^{73}$ and association. ${ }^{74}$ The Belgian legislator would thus have prohibited certain interpretations while referring to human rights law, alhough

67 'Rechten en fundamentele vrijheden' in the Dutch version, 'droits et libertés fondamentales' in the French version, 'Rechte oder Grundfreiheiten' in the German version.

68 It should be observed that the European Union only referred to 'fundamental principles' of certain basic rights and freedoms in its Framework Decision 2008/919/JHA which was criticised by some, see International Commission of Jurists, op. cit., p. 7 .

69 See Parl. Doc. Chamber of Representatives 2012-13, 2502/o01, p. 20.

70 Advice Council of State, Parl. Doc. Chamber of Representatives 2012-13, 2502/oo1, p. 28.

71 Parl. Doc. Chamber of Representatives 2012-13, 2502/001, p. 18.

72 See, e.g., Article 19(2) and 19(3) ICCPR, Article 10 ECHR and Article 11 EU Charter of Fundamental Rights.

73 See, e.g., Article 21 ICCPR, Article 11 ECHR and Article 12 EU Charter of Fundamental Rights.

74 See, e.g., Article 22 ICCPR, Article 11 ECHR and Article 12 EU Charter of Fundamental Rights. 
human rights would actually have allowed such readings. More importantly, it would have taken away (almost) all meaning of the new offences included in Articles 140 bis to 140 quinquies C.C., for, as said, they intrinsically reduce or restrict one or more fundamental rights. Consequently, Article 141ter C.C. could actually have prohibited that these provisions would have been interpreted or applied in the manner that they were meant to.

Unfortunately, this was not a timely and necessary save from the Council of State. The legislator had simply taken the reference to all reductions and restrictions of rights and fundamental freedoms from original Article 14iter C.C., as it had been included in the Criminal Code by the Law of 2003. This means that, for almost ten years, the provision which the Council of State correctly identified as 'legally unfitting' formed part of the applicable legal framework. Even if the Law of 2013 seriously expanded the scope of criminalised terrorist activities with the far more open 'terrorist recruitment, education and provocation', consequently increasing the risk of violating certain fundamental rights and freedoms, it should be clear that the already established offences in Articles 137 to 141 C.C. also interfered with the human rights framework; otherwise Article 14ter would not have been created from the beginning. Mention can once again be made of, for instance, the offences related to terrorist groupings and the fundamental freedoms of association and assembly. ${ }^{75}$ This was even confirmed by the Court of Appeals of Antwerp in a judgment of 2008, in which it explicitly referred to Article 141ter C.C. and the rights therein included when concluding that the accused did not form a terrorist group. ${ }^{76}$ At the same time, this judgment could be taken to prove that even though the language of Article 141ter C.C. was flawed, the judicial authorities interpreted and applied it in the manner as it had been intended by the Belgian legislator. Moreover, one can refer to the ECHR and EU Charter, which remain(ed) applicable and in light of which the Belgian provision should have been interpreted. But that still does not change the fact that the legislator had needlessly included a complicating contradiction in its legislation.

\subsection{Referring to Certain Specific Rights Creates a Risk of Rigidity and Restrictions}

The legislator could have sufficed in stipulating that 'no provision of Title Iter of the Criminal Code can be interpreted in a manner that would violate human rights and fundamental freedoms'. In doing so, it would have been clear and,

75 Supra Section 1.

76 Ct. Appeals Antwerp 7 February 2008, No 7 FP 2007, pp. 149-159, available online at http:// www.juridat.be. 
above all, all-encompassing. Unfortunately, the legislator chose to be more specific and referred explicitly to the right to strike, the freedom of assembly, of association and of expression, including the right to form or join trade unions with others for the protection of proper interests, and the related right to demonstrate. In 2013, it furthermore added the freedom of the press and the freedom of expression in other media. To be as complete as possible, it also included an express reference to the corresponding Articles 8 to 11 of the ECHR.

The objective, of course, was to underscore the importance of these particular rights and freedoms. Nonetheless, it also provokes the question: what about other rights, such as the right to privacy, the respect for family life, the freedom of religion...? By not mentioning them explicitly in the list, could it not be deduced that, a contrario, these rights and freedoms are of no particular interest in this regard and they can be violated? Naturally, this too should be answered in the negative. As was already indicated above, all human rights should be respected as a rule, whether or not this has been stated explicitly. In addition, and to the Belgian legislator's defence, the language of Article 141ter C.C. was copied almost word for word from the European instruments. Moreover, one could argue that the rights and freedoms that have been mentioned are, on the face of it, put most at risk by the new offences. Finally, Article 141 ter C.C. clearly refers to rights and fundamental freedoms 'such as' the right to strike, the freedom of assembly and association etc. These two short words right in the middle make clear that the list is non-exhaustive and merely illustrative.

That being said, the decision to only mention those specific rights still attracts criticism of rigidity and over-restrictive readings. To begin with, it is not because the European Council only mentioned certain rights that the Belgian legislator should have done the same. Moreover, if one were to be very precise, the European legislators actually also referred explicitly to other human rights and fundamental freedoms, such as the right to respect for private and family life, including the right to respect of the confidentiality of correspondence, ${ }^{77}$ and the freedom of religion. ${ }^{78}$ Why did the Belgian legislator not include those rights in the list? ${ }^{79}$ There is no reason to believe that they are less important in this respect, on the contrary even. This furthermore points to another problem. In 2013, the legislator felt the need to amend Article 141ter C.C. in order to insert a reference to additional human rights, apparently to

\footnotetext{
77 Preambular paragraph 13 Framework Decision 2008/919/JHA.

78 Article 12 COE Convention on the Prevention of Terrorism.

79 Although by referring to Articles 8 to 11 ECHR, it did implicitly also include the right to private and family life (Article 8 ECHR) and the freedom of religion (Article 9 ECHR).
} 
make sure that the provision would be in line with new evolutions and changes. Should one now expect the legislator to amend this provision every time terrorism, the criminal law framework against it and/or human rights principles will further evolve? That would hardly be practical and would not add to a level of legal certainty. If one could argue that a flexible definition of terrorism is preferable, ${ }^{80}$ a rigid and ad hoc human rights provision must surely be considered inferior too. Finally, the Belgian legislator chose to make an express reference to specific articles of the ECHR. The Framework Decisions did not directly do so, ${ }^{81}$ whereas Article 12 COE Convention on the Prevention of Terrorism, which did refer to the ECHR, only denoted the convention in general, without picking any particular provisions, and additionally mentioned human rights obligations set forth in the ICCPR and 'other obligations under international law'. Why then did the Belgian legislator have to include only those four provisions of the ECHR? Why did it limit itself to those particular provisions? The risk again is that this decision could - incorrectly - be interpreted as limiting the scope of Article 141ter C.C. to only those rights in that convention, or at least, putting those rights forward as the most important. This might be concerning, because notwithstanding the broad interpretations that are given to the provisions of the ECHR, they are not catch-all provisions. Other rights and freedoms and other binding instruments - such as, for instance, the far more detailed European Charter on Fundamental Rights - could potentially provide greater protection, especially given the developing nature of the human rights body. It would be a great shame if the overzealous nature of the Belgian legislator would give way to interpretations which question the full protection of the human rights framework rather than strengthen it.

\subsection{Human Rights Should Not Be Projected as the Sole Limit to the Interpretation of Criminal Provisions}

A last but must fundamental issue pertains to the relationship between human rights and criminal offences and, in particular, how one can be used as an aid or a guideline in order to interpret the other.

Human rights law and criminal law are, on certain points, very intertwined, and the manner in which a human right is construed must also determine what meaning ought to be given to a crime. Human rights are in fact a most important element to take into account as one of the limits to the interpretation of a

8 See, e.g., B. Golder and G. Williams, op. cit., p. 294. Compare C. Begorre-Bret, op. cit., pp. 1987-2004.

81 The ECHR and EU Charter of Fundamental Rights are only mentioned in the preambular paragraphs of the Framework Decisions, not in their legally binding provisions. 
crime or an offence: what is a fundamental right ought not to be a crime. However, as Article 141ter C.C. looks right now, it could give the appearance as if human rights might be the only limit to the interpretation and application of the terrorist offences included in Title Iter of the Criminal Code; an appearance which is only reinforced when Article 141ter C.C. is described as 'a ground of exclusion'. ${ }^{82}$ It gives the impression as if an authority, including a judge, may interpret the criminal offenses as broad as it wants, as long as it does not violate (certain) human rights. Everything that would not be protected as a fundamental right could and would then be considered criminal conduct, for either it is a fundamental right, or it is a crime.

Nevertheless, this would be jumping from black to white, ignoring all the grey in between. Just like not everything becomes a crime simply because it is forbidden, ${ }^{83}$ it is even more absurd to claim that everything that is not protected as a fundamental right constitutes criminal behavior. There is an entire greyscale in between: from human right to just a right or lawful conduct, to illegal behaviour, to finally a criminal act. Human rights and fundamental freedoms are in effect one limit to the interpretation of criminal provisions, but they are only one of several. Very important in this regard is one of the most basic criminal law principles, according to which all criminal provisions should be interpreted in a strict manner. Even though purposive and expansive interpretations are not necessarily precluded, a literal reading of a criminal law provision is the first way to go. Never ever may a judge expand a criminal provision per analogiam to instances that are not covered by the words of the provision, be it explicitly or, at the very least, implicitly. ${ }^{84}$ Given that the Belgian Constitutional Court even expressly reminded judges of the obligation to strictly interpret the provisions on terrorist offences, ${ }^{85}$ this basic rule should always be kept in mind: it is not an offence unless the legislator has said so in an explicit or, at least, implicit manner. A prosecuting authority and/or a court should therefore always look first at the criminal provision in question. If the behaviour is not prohibited by its wording, it is not a crime, regardless of the fact that the conduct in question was illegal, lawful or protected by a human

82 See A. De Nauw, Inleiding tot het bijzonder strafrecht [Introduction to specific criminal law] (Mechelen: Kluwer, 2010) p. 8.

83 See, e.g., ICTY, Prosecutor v. Vasiljević, Case No. IT-98-32-T, Trial Chamber, Judgement, 26 November 2002, para. 199 .

84 C. Van den Wyngaert with the help of S. Vandromme, Strafrecht en Strafprocesrecht in hoofdlijnen. DeelI [Basic Principles of Criminal law and Criminal Procedure. Part I] (Antwerp: Maklu, 2011) pp. 82-88 (except for interpretations per analogiam in bonam partem).

85 Arbitration Court 13 July 2005, No. 125/2005, Official Gazette 3 August 2005, pp. B.7.2. 
right. Only when the conduct could potentially fall under a criminal provision, should a judge be very careful that his interpretation does not violate human rights.

It could be argued, though, that such a restrictive interpretation is a corollary of the principle of legality, ${ }^{86}$ which in itself is already a human right. ${ }^{87} \mathrm{As}$ a result, such a restrictive interpretation would already be put forward in an indirect manner by Article 141ter C.C. as one of the guidelines authorities need to follow. Yet, if one looks at the wording of this provision - which does not say anything about the principle of legality and does not refer to the relevant Article 7 ECHR - and takes into account the travaux préparatoires, one cannot but conclude that it was not this core right which the legislator had in mind. The latter was rather thinking of the freedoms of expression, association and assembly, and the other specific and related rights that were mentioned supra. Given the at times vague and generic phrasing of Articles 137-141 C.C., it is not precluded that an argument is made that implicitly - id est, by interpreting the law in a lawful purposive manner ${ }^{88}$ — the legislator actually did want to criminalise a fairly broad range of conduct; that, by inserting Article 141ter C.C., the legislator actually wanted to indicate that all that is not protected by those specific human rights should be considered (possible) criminal behaviour. Some pretty extensive interpretations have in fact already been given to offences related to terrorism in recent years, ${ }^{89}$ which only further feeds this fear and criticism. As a result, rather than strengthening human

86 See, e.g., ECtHR, Maktouf and Damjanović v. Bosnia and Herzegovina, Appl. Nos. 2312/o8 and 24179/o8, Judgment, 18 July 2013, para. 66, available online at http://www.echr.coe.int (criminal law may not be extensively construed, e.g., by analogy).

$87 \quad$ Supra Section 3.1.

88 The ECtHR accepts judicial law-making to adapt criminal law to changing circumstances. See e.g. ECtHR, Khodorkovskiy and Lebedev v. Russia, Appl. Nos. 11082/06 and 13772/05, Judgment, 25 July 2013, para. 780: 'The Court stresses that ' in any system of law, including criminal law, however clearly drafted a legal provision may be, there is an inevitable element of judicial interpretation. There will always be a need for elucidation of doubtful points and for adaptation to changing circumstances' (...). Furthermore, in most of the member States, the progressive development of the criminal law through judicial law-making is a wellentrenched and necessary part of legal tradition. Article 7 of the Convention cannot be read as outlawing the gradual clarification of the rules of criminal liability through judicial interpretation from case to case, provided that the resultant development is consistent with the essence of the offence and could reasonably be foreseen (...).' Available online at http:// www.echr.coe.int.

89 E.g., the ruling of the Court of Appeals of Ghent of 7 December 2006 (149 Juristenkrant (2007) p. 4 (reproduced by P. Herbots)) in the DHKP-C case. See also A. Weyembergh and L. Kennes, op. cit., pp. 157-164. 
rights protection, the legislator might have set the door open for a broad sweeping criminalisation.

\section{$4 \quad$ Conclusion}

Even though the inclusion of a human rights clause in Article 141ter of the Criminal Code seems somewhat odd and unnecessary, one would still think of it as a commendable initiative at first sight, born out of good intentions. At best, one could assert that Belgium fully fulfilled any implementation obligations it might have had on this point, given that it transposed the relevant provisions in the European instruments in a near verbatim manner. However, this article indicated that there was no immediate obligation to implement such a human rights clause, ${ }^{90}$ and it was contended that including such a provision in a criminal code in the manner in which the Belgian legislator did, is not only superfluous but also unwise and even hazardous. The recent Law of 2013 should therefore be considered a missed opportunity: it was a perfect occasion to retract Article 141ter, but the Belgian legislator chose not to do so and rather made this human rights clause even more specific, thus further adding to the potential confusion.

It could be argued, on the one hand, that the European legislators are to blame, as they should not have included such provisions in their instruments. However, as was illustrated in this article, there can be very good reasons for the international legislators to adopt such provisions, given, for instance, the potential for conflicting international obligations. States should rather understand such provisions as general — binding — guidelines, but not as provisions that need to be implemented in a literal manner.

On the other hand, it could be claimed that it is not the first time a State has referred explicitly to human rights obligations in its criminal legislation. For instance, in its respective laws on extradition procedures ${ }^{91}$ and the European arrest warrant, ${ }^{92}$ the Belgian legislator ${ }^{93}$ also included grounds of refusal for

9o When drafting the Law of 2013, it was observed that legislator(s) only disposed of a limited margin of appreciation, Parl. Doc. Chamber of Representatives 2012-13, 2502/004, 5. But as was indicated (see fn. 29), the Council of State rightfully observed that there was no duty to also implement Article 2 Framework Decision 2008/919/JHA.

91 Article 2bis Uitleveringswet 15 maart 1874 [Extradition law of 15 March 1874], Official Gazette 17 March 1874.

92 Article 4, $5^{\circ}$ Wet 19 december 2003 betreffende het Europees aanhoudingsbevel [Law of 19 December 2003 regarding the European Arrest Warrant], Official Gazette 22 December 2003.

93 Like several other States, see Commission Staff Working Document - Annex to the Report from the Commission on the implementation since 2005 of the Council Framework 
reasons that the extradition or surrender in question would violate the basic rights and freedoms of the person concerned. Nevertheless, given the fact that such a human rights exception to extradition is still relatively new ${ }^{94}$ and still forming, and the European legislator completely omitted to insert such a ground of refusal in its original Framework Decision, ${ }^{95}$ one can see the need to explicitly foresee such a clause, because it might not always be self-evident for international cooperation to be obstructed by human rights principles. It is, on the other hand, indisputable that a judge may not violate human rights when interpreting and applying provisions in its own criminal code that describe and punish specific criminal behaviour. ${ }^{96}$ Given that human rights and fundamental freedoms will principally apply in all criminal cases, there does not seem to be a definite need to insert human rights provisions like Article 14iter C.C. in a criminal code. If the legislator would like to warn about the risks that certain new legislation could be interpreted in violation of core rights, it seems more appropriate to do so in the travaux préparatoires, as a cautionary principle. ${ }^{97}$

It should be noted, though, that up until now Article 141ter C.C. has caused more bewilderment than actual harm, because, to this author's knowledge, it has not yet been 'misused' in criminal proceedings. Moreover, all the foregoing does not necessarily mean that there could never be any place for human rights and fundamental freedoms in a criminal code. The Dutch Criminal Code, for instance, previously emphasised multiple times that certain fundamental freedoms could not be violated when executing a punishment. ${ }^{98}$ One should, nonetheless, observe that those provisions were included in the

Decision of 13 June 2002 on the European arrest warrant and the surrender procedures between Member States, Brussels, 11 July 2007, SEC 979 (2007) pp. 8-11 .

94 It was only in 1989, in the renowned Soering case, that the ECtHR said so for the first time, ECtHR, Soering v. the United Kingdom, Appl. No. 14038/88, Judgment, 7 July 1989, Series A No. 161 .

95 See Council Framework Decision 2002/584/JHA of 13 June 2002 on the European arrest warrant and the surrender procedures between Member States, OJ L 190, 18 July 2002, p. 1.

96 Cf., Belgian Supreme Court 20 April 1950, Pasicrisie belge 195o, I, p. 56o (a judge may not apply a royal decree that violates the Belgian Constitution).

97 E.g., a draft bill that has been submitted to parliament on 26 February 2013 to implement the Convention for the Suppression of Acts of Nuclear Terrorism. In the commentary on draft Article 2, the wording of Article 141ter is fully reiterated (two times even). However, it is not proposed to include this clause as such in the (draft) bill or the Criminal Code. See Parl. Doc. Chamber of Representatives 2012-13, 2672/001, pp. 7-8, 13 and 41-51.

98 See former Article 14(c)(3) and 15(a)(4) Dutch Criminal Code (prior to being amended by Law of 17 November 2011, Staatsblad 2011, p. 545). 
beginning of the general part of that criminal code, thus referring to all sorts of different crimes and punishments to which they basically applied. As was stated before, it might indeed be useful just to remind in a general and open manner that a criminal code may never be applied in a manner that is contrary to basic rights. But then a State - like Belgium — should not do so in a multitude of specific and detailed provisions that only refer to particular offenses. It should rather draft such an all-embracing and general article, stipulating that "no provision in this code may ever be interpreted or applied in a manner that is in violation of human rights and fundamental freedoms", which it should then include at the very beginning of its criminal code, and would therefore apply to the entire code and all of the offences therein included. It could still be up for debate whether such a provision would truly be necessary or useful, but at the very least, it would not entail all the risks current Article 141ter C.C. is surrounded with. 